\title{
Party Discipline and Government Spending: Theory and Evidence*
}

\author{
Marta Curto-Grau ${ }^{\dagger}$ \\ Galina Zudenkova ${ }^{\ddagger}$ \\ University of Barcelona \&3 BEAT \&3 IEB \& IPErG University of Mannheim
}

\begin{abstract}
This paper studies the relationship between party discipline and discretionary spending with theory and data. We propose a theoretical model in which a politician faces a conflict between her constituents' interests and the party line. Party loyalty is electorally costly for the politician and is therefore rewarded by the party leader with greater amounts of discretionary spending allocated to the politician's constituency. This effect is greater the more intense the conflict between the voters' and the party's interests. Using data on party discipline in the U.S. House of Representatives and federal payments to congressional districts between 1986 and 2010, we provide evidence that increases in legislators' party discipline raise the amounts of discretionary spending their districts receive. The rewards for discipline are larger the greater the gap between the constituents' and party's preferences (i.e., in conservative-leaning districts represented by Democrats or liberal-leaning districts represented by Republicans).
\end{abstract}

JEL classification: D72, H41.

Keywords: Party discipline; discretionary spending; party line.

${ }^{*}$ The authors are grateful to two referees, the editor (Fernando Ferreira), James Snyder, Pilar SorribasNavarro, and seminar and conference participants at several institutions for helpful comments and suggestions, and Lutz Brückner, Alina Gaisbauer, and Jonas Metzger for excellent research assistance. Zudenkova acknowledges financial support from the German Science Foundation (research project SFB 884-C1) and Curto-Grau from the European Commission (project 749547-POLITRAITS). An earlier-and very different-version of this paper circulated under the title "Party Discipline in Congress." The usual disclaimer applies.

${ }^{\dagger}$ Department of Economic History, University of Barcelona, 08034 Barcelona, Spain. E-mail address: mcurto@ub.edu.

${ }^{\ddagger}$ Department of Economics, University of Mannheim, D-68131 Mannheim, Germany. E-mail address: galina.zudenkova@gmail.com. 


\section{Introduction}

Party discipline commonly refers to the ability of party leaders to influence their party members to support the party line on the floor of the legislature. ${ }^{1}$ In modern democracies, party discipline is often difficult to achieve because legislators have to respond to local needs and preferences that are sometimes not aligned with the party's interests. Excessive party loyalty, therefore, may be electorally costly for legislators. To soften electoral punishment and foster party discipline, party leaders may reward loyalty. Such rewards can include "favorable committee assignments and leadership positions, campaign funds, district visits by party notables, federal projects targeted to a member's district, expedited treatment for a member's favorite bills, and invitations to serve as speaker pro tem" (Snyder and Groseclose 2000, p. 194). Narrowly targeted projects may be particularly effective in influencing legislators' voting behavior. In 1964, for instance, American President Lyndon Johnson persuaded Arizona Democrat Carl Hayden to vote in favor of the Civil Rights Act in exchange for the Central Arizona Water Project that Hayden's constituents demanded. Some argue that "without a little pork, Johnson would have been unable to obtain his [Hayden's] support" (Zelizer, 2014).

More recently, in 2011, the U.S. Congress banned earmarks as they were often associated with overspending and corruption. However, this came at the cost of the Congress being more paralyzed and less able to pass fundamental legislation because congressional leaders could no longer reward and punish rank-and-file members. ${ }^{2}$ According to Republican former Senate Majority Leader Trent Lott, "trying to be a leader where you have no sticks and very few carrots is dang near impossible." ${ }^{3}$ Nowadays, the Congress has reached such a high level of dysfunction that even Republicans (including President Donald Trump), who have traditionally opposed earmarks, are suggesting it may be time to bring them back. ${ }^{4}$

However, besides anecdotal evidence, there is a great deal of uncertainty regarding the relationship between party discipline and the allocation of discretionary spending. ${ }^{5}$ The present

\footnotetext{
${ }^{1}$ Henceforth, we use the terms party discipline and party loyalty interchangeably.

${ }^{2}$ See for instance, https ://www.vox.com/2015/6/30/8864869/earmarks-pork-congress

${ }^{3}$ Quote extracted from:

https://www. theatlantic.com/magazine/archive/2016/07/how-american-politics-went-insane/ 485570/

${ }^{4}$ See for instance some debates in newspapers and blogs: https://www .vox.com/policy-and-politics/2018/1/12/16873520/case-for-and-against-earmarks https : //www . washingtontimes . com/news/2018/jan/17/republicans-democrats-agree-need-earmark-spending/

${ }^{5}$ Discretionary spending typically refers to federal spending that is included in annual appropriation bills, as opposed to mandatory spending. Also, it is a kind of payment that can be targeted to certain constituencies and that is not based on objective formulas. Henceforth, we use the terms discretionary spending and porkbarrel spending interchangeably.
} 
paper contributes to this line of research by proposing and testing empirically a novel theory that identifies the condition under which party discipline is likely to influence government spending. In our model, voters condition a politician's reelection on the policy outcome she decides to implement, as well as on the amount of funds she attracts for her constituency. If the politician (who is purely office-motivated) follows the party line instead of voters' interests, the potential electoral punishment can be partly (or totally) offset by larger spending targeted to her constituency. The party leader, who is in charge of allocating government spending, offers a contract to the politician conditioning the allocation of spending on the politician's loyalty to the party line. In this context, the closer the policy outcome to the party line, the more loyal the politician is. Our model predicts that higher levels of party loyalty are associated with greater amounts of targeted spending. Most importantly, this effect is greater the more intense the conflict between the party leader's preferences and the voters' interests.

To investigate empirically the relationship between party discipline and discretionary spending, we use a dataset of congressional districts in the United States that includes information on representation and party discipline in the House of Representatives and federal grants between 1986 and 2010. We focus on party loyalty in legislative voting and use as a measure of discipline the party unity scores published yearly by Congressional Quarterly. These scores are based on roll-call votes in which the majority of Democrats oppose the majority of Republicans, also known as unity votes. Unity scores are calculated as the percentage of unity votes in which a representative voted along her party line. In addition, to measure the intensity of conflict between the party's and voters' interests, we use districts' vote shares in the preceding presidential elections. The results of presidential elections are commonly used to measure district ideology in the liberal-conservative dimension. Larger vote shares of a Republican (Democratic) presidential candidate in districts represented by Democratic (Republican) House members indicate a larger gap between constituents' and party's interests. As for the type of federal grants, we restrict our analysis to spending programs that have a large variation over time within districts and are likely to be allocated according to discretionary rules. Thus, this type of expenditure is more susceptible to political manipulation and targeting.

We apply two estimation strategies to examine empirically our theoretical predictions. The first strategy is to include district and year fixed effects as well as a set of legislators' observable characteristics (e.g., partisanship) and district characteristics (e.g., whether the district partisanship aligns with that of the House majority or the President). The inclusion of district fixed effects mitigates to a certain extent the potential omitted-variable bias. How- 
ever, another concern is the simultaneity bias. To address this issue, we instrument party discipline with a two-year lag of party unity scores. Given that congressional elections take place every two years and that our analysis focuses on new payments (excluding multi-year projects), it is unlikely that current spending is exchanged for future discipline, when neither leaders nor rank-and-file members can predict their electoral prospects.

According to our results, a one-standard deviation increase in party unity scores raises discretionary spending by $18 \%$ on average. We also find, in line with our theoretical predictions, that a one-standard deviation increase in conflict intensity raises the reward to party discipline by about 5\%. According to our results, the OLS estimates underestimate the true effect of party discipline. A possible explanation is that party discipline is targeted to legislators who would otherwise disregard the party line. If this is effective in changing their vote then observed values of party discipline are already the result of higher levels of spending.

The remainder of the paper is organized as follows. The next section describes the related literature. Section 3 outlines the theoretical model and derives its empirical implications. Section 4 describes the data and illustrates the empirical strategy. Section 5 presents the estimation results and robustness checks. Finally, Section 6 concludes the paper.

\section{Related Literature}

Our theoretical model contributes to the formal literature on party discipline, which comprises several approaches. Some researchers have elaborated on informational arguments, pointing out that strong party discipline informs voters about the future policy of a candidate who, once elected, cannot deviate from the party's official platform (Ashworth and Bueno de Mesquita 2004; Castanheira and Crutzen 2010; Cox and McCubbins 1993; Snyder and Ting 2002). In a similar vein, Grossman and Helpman (2008) defined party discipline as a party's ability to induce ex-post adherence to a pre-announced position. Party discipline, therefore, is a valuable asset for the party leaders because it signals cohesion and thus helps build a political brand (Cox and McCubbins 1993). In several other studies, party discipline has been modeled as the ability of the party leadership to control its members in the legislature such that they vote in line with the party's ideological position (Colomer 2005; Eguia 2011; Iaryczower 2008; McGillivray 1997; Patty 2008; Volden and Bergman 2006). In these models, the party leader's objective is to discipline party members who might have different ideological preferences. Among these studies, the most related to ours is Iaryczower (2008) who analyzed a similar setting but focused on the impacts of partisan promises (such as nomination to party lists) on loyalty in voting. He defined party discipline as "power of partisan promises to induce 
behavior different than in a non-partisan benchmark" (p. 205), and modeled pork-barrel spending as a tool to coordinate party members' beliefs about the leader's ability to provide future partisan benefits. We do not consider partisan promises but rather concentrate on the conditions under which party loyalty is likely to influence pork-barrel spending. In turn, Diermeier and Feddersen (1998a,b) provided an institutional explanation for cohesive voting of legislators in parliamentary systems. The authors showed that the vote-of-confidence procedure common in parliamentary democracies creates an incentive for cohesion in voting.

Although these studies formally analyzed party discipline, little research has been conducted on the impacts of party loyalty on the allocation of discretionary spending. We are aware of only one formal study that addresses this question. Grossman and Helpman (2008) investigate how differences in party discipline affect national spending on local public goods. In the study's setting, however, party discipline is modeled as an exogenously given institutional variable - an "extent of commitment to party platforms" (p. 330). In the present paper, we endogenize party discipline by modeling explicitly the politician's and the party leader's problems.

This paper also contributes to the empirical literature on party discipline, which has mostly focused on the political consequences of loyalty. There is evidence of loyal legislators incurring electoral punishment in the polls (Carson et al. 2010). Some studies have shown that party lines affect legislators' voting behavior on the floor of the legislature (Heller and Mershon 2008; Krehbiel 2000; McCarty, Poole and Rosenthal 2001; Rohde 1991; Snyder and Groseclose 2000). Barber, Canes-Wrone and Godbout (2014) also found that, in the US, majority party leaders reward loyalty in roll-call voting with campaign contributions to run in upcoming elections.

Our paper is also related to the studies on the relationship between legislative representation and the geographic distribution of public spending. Atlas et al. (1995) find that per-capita federal spending is correlated with per-capita representation in the U.S. Senate. Using data on U.S. transportation projects, Knight (2004) finds that legislators are more likely to support federal spending the higher their own-district spending and the lower the tax burden borne. Knight (2008) analyzed the relationship between legislative representation and the geographic distribution of federal spending. He finds that small U.S. states receive more funding in the Senate, while large U.S. states receive more funding in the House. In turn, Albouy (2013) finds that U.S. states represented by the majority party members receive more federal funds than those represented by members in the minority. More broadly, this paper contributes to the literature on distributive politics that focuses on the political distribution of public goods. Most of this literature focuses on four main political factors 
that influence the distribution of government spending: core and swing districts (Lindbeck and Weibull 1987; Dixit and Londregan 1996), partisan favoritism (Arulampalam et al. 2009; Brollo and Nannicini 2012), clientelism (Stokes et al. 2013), and political budget cycles (Shi and Svensson 2016). ${ }^{6}$

Although these studies have empirically investigated party loyalty and the allocation of federal funds as unrelated topics, evidence for the relationship between party discipline and discretionary spending is scarce. To the best of our knowledge, only two studies have addressed this issue, and the results are mixed. Primo and Snyder (2010) find that, for the years 1957-1970, U.S. states with strong party organizations received less federal spending than states with weaker parties. ${ }^{7}$ However, the result is no longer statistically significant once state fixed effects are included. A negative relationship between legislative party strength and federal grants would be at odds with the fact that since the early 1990s and until 2011, when earmarks were banned, the U.S. has experienced an increase in party cohesion and pork-barrel spending. This pattern is more consistent with the idea of pork as a reward for party loyalty. Pearson (2008) suggests that this may be the case: "When party leaders in both chambers finalize the details of major legislation, they have opportunities to reward loyalty. The increasing number of earmarks added in conference committee or during budget summit negotiation may provide limited opportunities to reward loyalty" (p. 113). This observation is in line with the findings of Cann and Sidman (2011) who report a positive correlation between party loyalty and government spending for U.S. representatives in 2002-2009.

We depart from Cann and Sidman's analysis in several ways. First, our model identifies the conditions under which party discipline is likely to be highly rewarded (i.e., in the districts with conflict between the constituents' interests and the party line). If no conflict of interest exists, then legislators vote along party lines simply because the constituents' preferences are aligned with the party's. In this case, a positive relationship between spending and discipline is just a spurious correlation. Second, we expand the time period to the years 1986-2010. This is important because in the 1980s and 1990s, there was a larger number of Republican representatives in liberal-leaning districts and Democrat representatives in conservative-leaning districts. Third, to address the potential bias due to simultaneity between loyalty and spending, we use an instrumental variables approach in contrast to Cann and Sidman's random-effects model.

\footnotetext{
${ }^{6}$ See Golden and Min (2013) for an extensive review.

${ }^{7}$ Their measure of party strength is an index constructed by Zeller (1954), who classifies states as those with strong party organizations and those with weak party organizations. The classification is based on the results of a survey conducted among experts.
} 


\section{Model}

Consider a politician who decides on policy $x$. The set of feasible policies is taken to be the closed interval $[0, l], l>0$. The politician is assumed to be purely office-motivated and to maximize her reelection probability denoted by $\operatorname{Pr}(\cdot)$.

There is a representative voter with bliss point 0 who cares about the policy outcome $x$ according to the function $v(x)$, where $v:[0, l] \rightarrow \mathbb{R}$ is a strictly decreasing, twice-differentiable and concave function. Therefore, the voter prefers the policy to be as close as possible to his bliss point 0 . The voter also values discretionary spending $s$ that enters linearly into his utility function

$$
u_{V}(x, s)=v(x)+s .
$$

One can think of $s$ as specific projects or public goods.

The voter decides on the politician's reelection. He realizes that the politician wants to be reelected. Therefore, the politician can be held accountable for the policy outcome and discretionary spending at the moment of the election. We assume that the voter conditions the politician's reelection on the voter's utility $u_{V}(x, s)$ from policy $x$ and spending $s$. The higher $u_{V}(x, s)$, the more likely the voter is to reelect the incumbent. The probability of reelection is given by

$$
\operatorname{Pr}(x, s)=F\left(u_{V}(x, s)\right),
$$

where $F(\cdot)$ denotes the cumulative function of a well-behaved continuous distribution with $F^{\prime}(\cdot)>0 .^{8}$

The politician is affiliated with a political party. The party leader with bliss point $l$ is policy-motivated. ${ }^{9}$ He cares about the policy outcome $x$ according to the function $v(l-x)$. The party leader thus wants the politician to choose a policy as close as possible to the party leader's own bliss point $l$, which we refer to as the party line. ${ }^{10}$ However, supporting the party line is electorally costly for the politician as the voter wants the politician to implement a policy sufficiently close to his bliss point 0 . This implies that there exists a conflict of interest between the voter's interests (i.e., his bliss point 0) and the party line (i.e., the party leader's

\footnotetext{
${ }^{8}$ Alternatively, one can assume that the politician cares about her constituency (instead of her reelection prospects) and so maximizes the voter's utility $u_{V}(x, s)$ (instead of the reelection probability $F\left(u_{V}(x, s)\right)$ ). The model predictions do not change in this case.

${ }^{9}$ In Appendix C, we extend the model by assuming that the party leader is both policy- and office-motivated with the objective to maximize both his utility from the policy outcome and the politician's reelection chances. We show that our theoretical insights hold in this case.

${ }^{10}$ The assumption that the voter's and the leader's bliss points are at the opposite extremes of the policy space $[0, l]$ is made without loss of generality.
} 
bliss point $l$ ). A larger $l$ makes this conflict between the voter's and the leader's interests more intense.

We assume that the party leader controls the allocation of discretionary spending $s \geq 0$ that he can channel to the politician's constituency (for example, via earmarks). ${ }^{11}$

The party leader's utility function is therefore given by

$$
u_{L}(x, s)=v(l-x)-s .
$$

The party leader knows that the politician maximizes her reelection probability $\operatorname{Pr}(x, s)$, which depends on the policy outcome $x$ and on the amount of spending $s$. Therefore, the party leader can somehow compensate the politician with spending for supporting the party line instead of following her constituency's interests. In other words, the party leader can reward the politician's loyalty and discipline with spending channeled to her constituency. We measure the politician's loyalty to the party line (i.e., her party discipline) with $x$. A larger $x$ means that the politician implements a policy closer to the party line $l$ (and so is more loyal and disciplined).

The party leader wants the politician to internalize his losses $v(l-x)$ from the implemented policy and so will condition discretionary spending $s$ on these losses. This is modeled as an explicit contract that maps any possible policy to the spending allocation:

$$
s(x)=\max [v(l-x)+\alpha, 0],
$$

where $\alpha \in \mathbb{R}$ is a constant chosen optimally by the party leader. The more loyal the politician (i.e., the closer $x$ to the party line $l$ ), the larger the amount of spending is allocated to her constituency.

The timing of events is as follows. The party leader chooses $\alpha$ and offers $s(x)$ to the politician, giving a binding promise of spending conditional on the chosen policy level $x$. The politician either accepts or rejects this offer (she is assumed to accept if she is indifferent). ${ }^{12}$ Finally, she chooses policy $x$. If she is indifferent between several policies, she picks the policy preferred by the party leader. ${ }^{13}$

\footnotetext{
${ }^{11}$ In the U.S. Congress, party leaders decide when to place bills for consideration and therefore have opportunities to add a number of earmarks when finalizing the details of major legislation. This suggests that party leaders have a certain level of power to allocate discretionary spending in their (or their party's) interests.

${ }^{12}$ Alternatively, one can assume that the party leader offers the politician a small positive compensation $\varepsilon>0$ in exchange for her accepting the spending offer when she is indifferent.

${ }^{13}$ Alternatively, one can assume that the party leader offers the politician a small positive compensation $\varepsilon>0$ in exchange for her selecting his preferred policy among the policies to which she is indifferent.
} 
We analyze this game backwards and turn now to the politician's policy choice and her decision whether to accept or to reject the party leader's offer.

Politician's policy choice Suppose first that the politician rejects the party leader's offer $s(x)$. This corresponds to the case with zero spending in which the probability of the politician being reelected to her office is equal to

$$
\operatorname{Pr}(x, 0)=F(v(x)) .
$$

The politician chooses $x \in[0, l]$ to maximize this probability. Given that $F^{\prime}(\cdot)>0$, she maximizes $v(x)$ (which is strictly decreasing) and thus picks the voter's preferred policy 0 . Her probability of reelection is equal to $F(v(0))$ in this case.

Suppose next that the politician accepts the party leader's offer $s(x)$ given by (1). Her reelection probability is then

$$
\operatorname{Pr}(x, s(x))=F(v(x)+\max [v(l-x)+\alpha, 0]) .
$$

The politician maximizes $\operatorname{Pr}(x, s(x))$ with respect to $x$. We denote with $x(\alpha)$ the politician's policy choice that depends on the party leader's choice of $\alpha$. $\operatorname{Pr}(\alpha)$ denotes the corresponding reelection probability. The politician's maximization problem is analyzed in Appendix B. The results are summarized in the following lemma.

Lemma 3.1. Suppose that the politician has accepted the party leader's offer $s(x)$ given by (1). Then she chooses policy

$$
x(\alpha)= \begin{cases}\frac{l}{2} \quad \text { if } \quad \alpha \geq v(0)-2 v\left(\frac{l}{2}\right), \\ 0 \quad \text { if } \quad \alpha<v(0)-2 v\left(\frac{l}{2}\right) .\end{cases}
$$

and gets reelected with probability

$$
\operatorname{Pr}(\alpha)= \begin{cases}F\left(2 v\left(\frac{l}{2}\right)+\alpha\right) & \text { if } \quad \alpha \geq v(0)-2 v\left(\frac{l}{2}\right), \\ F(v(0)) & \text { if } \alpha<v(0)-2 v\left(\frac{l}{2}\right) .\end{cases}
$$

Lemma 3.1 suggests that a higher $\alpha$ (i.e., a higher amount of discretionary spending) makes the politician pick a policy closer to the party leader's bliss point $l, \frac{l}{2}$ instead of 0 . Even though the voter prefers policy 0 to $\frac{l}{2}$, in the case of a higher $\alpha$ he gets compensated with discretionary spending and so reelects the politician with higher probability. For $\alpha \geq$ $v(0)-2 v\left(\frac{l}{2}\right), F\left(2 v\left(\frac{l}{2}\right)+\alpha\right) \geq F(v(0))$.

We next consider the politician's decision whether to accept or to reject $s(x)$. Comparing her reelection probability in the case of rejecting, $F(v(0))$, with that in the case of accepting, 
(3), yields that she has weakly higher chances of being reelected in the latter case. Note that for the case of $\alpha<v(0)-2 v\left(\frac{l}{2}\right)$, she is indifferent between accepting and rejecting $s(x)$. However, for the case of $\alpha \geq v(0)-2 v\left(\frac{l}{2}\right)$, she strictly prefers to accept $s(x)$. Therefore, for all $\alpha \in \mathbb{R}$, she decides to accept the spending offer of the party leader given by (1). In what follows, we turn to the party leader's decision about $\alpha$ that defines the reward for the politician's loyalty and discipline.

Party leader's choice of $\alpha$ The party leader realizes that the politician will accept his offer and will implement policy $x(\alpha)$ given by $(2)$. The party leader's utility $u_{L}(\cdot)$ is then equal to

$$
u_{L}(\alpha)=v(l-x(\alpha))-s(x(\alpha))=\left\{\begin{array}{lll}
-\alpha & \text { if } \quad \alpha \geq v(0)-2 v\left(\frac{l}{2}\right) \\
v(l) & \text { if } \quad \alpha<v(0)-2 v\left(\frac{l}{2}\right)
\end{array}\right.
$$

The party leader chooses $\alpha$ to maximize $u_{L}(\alpha)$, which is constant at $v(l)$ for $\alpha<v(0)-2 v\left(\frac{l}{2}\right)$, discontinuously jumps to $2 v\left(\frac{l}{2}\right)-v(0)$ at $\alpha=v(0)-2 v\left(\frac{l}{2}\right)$, and is strictly decreasing for $\alpha \geq v(0)-2 v\left(\frac{l}{2}\right)$. Therefore, the leader picks $\alpha^{*}=v(0)-2 v\left(\frac{l}{2}\right)$. His utility is then equal to $u_{L}\left(\alpha^{*}\right)=2 v\left(\frac{l}{2}\right)-v(0)$ and is higher than his utility when he makes no spending offer to the politician (which is $v(l)$ ). The politician gets utility $\operatorname{Pr}\left(\alpha^{*}\right)=F(v(0)$ ) while the voter gets utility $u_{V}\left(\alpha^{*}\right)=v(0)$, which are exactly equal to their utilities when no spending offer was made by the party leader. Therefore, in equilibrium, the party leader gets all the gains from the spending contract and just has to ensure that the politician's participation constraint binds. The spending contract is presented in the following Proposition.

Proposition 3.2. The party leader proposes the following spending contract to the politician

$$
s(x)=\max \left[v(l-x)+v(0)-2 v\left(\frac{l}{2}\right), 0\right] .
$$

The politician's discipline and the resulting spending allocation are determined in equilibrium, and, thus, both are endogenous. However, the model suggests that the two are correlated. According to (4), the party leader will condition the allocation of discretionary spending on the politician's loyalty to the party line $x$, as well as on the intensity of conflict between the constituency's and leader's policy preferences $l$. We turn now to the model's predictions which are tested in the following empirical analysis.

Prediction 1: The more loyal the politician is to the party line, the larger the amount of spending is allocated to her constituency: $\frac{\partial s}{\partial x} \geq 0$ for $x \in[0, l]$.

Intuitively, the model suggests that the party leader opts for the loyalty reward that maps a policy to a spending allocation. The closer the chosen policy to the party line (i.e., 
the more disciplined the politician), the higher the spending is channeled to the politician's constituency. Therefore, we expect a positive association between the politician's loyalty to her party and the discretionary spending allocated to her home district.

Prediction 2: The effect of the politician's loyalty on discretionary spending is larger the more intense the conflict of interest between the voter's and the party leader's preferences: $\frac{\partial^{2} s}{\partial x \partial l} \geq 0$.

This interaction effect between party discipline and conflict intensity reflects the innate nature of party loyalty. The politician's support for the party line does not necessarily imply she is being loyal to the party. In particular, in the absence of conflict between the voter's and the party leader's interests, the politician would face no trade-off. Then, supporting the party line would be a by-product of following her constituency's interests rather than a sign of party discipline and so does not have to be rewarded by the party leader. In turn, a conflict between the voter's and the party leader's preferences leads to a trade-off for the politician. In this case, there is room for party discipline that has to be rewarded by the party leader. The more intense the conflict of interest, the larger the trade-off is faced by the politician and thus the more she will be rewarded for a given level of party loyalty. As a result, not only does more party loyalty increase the amount of spending allocated to the politician's constituency, but it also does so to a larger extent if the conflict between the voter's and the party leader's interests deepens.

\section{Empirical Analysis}

In the empirical analysis, we study the relationship between party discipline and the allocation of public spending using district-level data on members of the U.S. House of Representatives and federal expenditures for the 1986-2010 period. We restrict the analysis to the House of Representatives because the Senate is composed of multi-member districts, and it is therefore hard to clearly relate the behavior of a legislator to the amount of spending her district receives. In contrast, the House of Representatives is composed of single-member districts. In what follows, we describe the methodology and data, and then present our results.

\subsection{Empirical Approach}

To test the two hypotheses presented in Section 3, we estimate the effect of party discipline on discretionary spending with the following regressions:

$$
y_{i t}=\beta_{1} \text { Unity }_{i t}+X_{i t}^{\prime} \Omega+\mu_{i}+\delta_{t}+u_{i t},
$$




$$
y_{i t}=\beta_{1} \text { Unity }_{i t}+\beta_{2} \text { Unity }_{i t} \times \text { Conflict intensity } y_{i t}+\beta_{3} \text { Conflict intensity }_{i t}+X_{i t}^{\prime} \Omega+\mu_{i}+\delta_{t}+u_{i t},(6
$$

where $i$ denotes congressional districts, $t$ denotes fiscal years, $\delta_{t}$ captures time effects, and $\mu_{i}$ refers to district fixed effects, where districts are constant units within each decennial census to address the complex issue of redistricting. Our dependent variable $y_{i t}$ is the log of discretionary spending per capita, in 2010 dollars (inflation adjusted). Following DeBacker (2011), we exclude continuing payments originated in previous years and only include new payments for which legislators can clearly claim credit. The main explanatory variable, party discipline, is captured by party unity scores $\left(U_{n i t} y_{i t}\right)$. These scores account for the frequency with which legislators vote in agreement with the party line on the floor of the House. ${ }^{14}$ Further, we use district-level vote shares in the preceding presidential election as proxies for district ideology and measure the degree of conflict faced by a legislator (Conflict intensityit) with her district's vote share of the presidential candidate affiliated with the opposing party. In other words, conflict is measured as the vote share of the Republican (Democratic) presidential candidate if the legislator is Democrat (Republican). Below we provide detailed description of these variables.

We also include in our regressions a set of district-level political variables $\left(X_{i t}^{\prime} \Omega\right)$ to capture the possibility that members with a certain partisanship have an agenda-setting advantage that helps them secure funding. This would be the case for members affiliated with the President's party (Berry, Burden and Howell 2010), and members of the House majority (Cox and McCubbins 1993; Albouy 2013). In addition, to account for different spending preferences across the Democratic and Republican parties (Ferreira and Gyourko 2009), we include in our regressions a binary variable that equals one if a representative is Republican. As in Dynes and Huber (2015), we add two binary variables that indicate whether the district is Republican-leaning and the President is Republican or the district is Republican-leaning and the House is controlled by Republicans. ${ }^{15}$

Socioeconomic variables such as unemployment and age structure may affect the spending needs of the population in a district. They are, however, not included as controls because they are available only at the district level from the decennial censuses. As these data do not vary within districts, they are captured by $\mu_{i}$.

\footnotetext{
${ }^{14}$ Recall that the budget of a certain fiscal year $t$ is approved during the previous year. In the process of approving the federal budget, members add pork to appropriation bills and exchange loyalty for spending that will be disbursed during the following year. Thus, rewards happen contemporaneously, which is in line with the quote from Pearson (2008) in Section 2.

${ }^{15}$ Although a legislator's seniority, leadership positions or committee membership may affect her capacity to attract funding to her district, they may also be the result of her level of party discipline. Therefore, these variables are not included in our regressions.
} 
According to our model, spending and party discipline are chosen at the same time, which poses an endogeneity threat. Moreover, the level of conflict a legislator is exposed to may also affect her roll call votes. To address this issue, we lag party unity scores two years and use this lagged variable as an instrument for current discipline. In the next section, we show that past discipline explains a large proportion of variation of current discipline and it is a strong instrument. In addition, for the instrument to be valid, lagged discipline should only be correlated with spending through current discipline. We argue that this is fulfilled because elections to the House of Representatives take place every two years and this means that our instrument captures voting behavior of legislators in the previous legislature. ${ }^{16}$ We believe it is unlikely that party leaders can credibly commit to reward legislators with pork-barrel spending in the next term (in two years) given that they do not know their electoral prospects (they may no longer be in Congress, or, if they are, they may face different constraints). Provided that our measure of pork barrel only considers new payments and not multi-year projects, it is quite improbable that the type of spending we analyze has been agreed in the previous legislature.

It is important to ensure that our instrument is not correlated with the degree of conflict between the voters' and party's interests. We can only guarantee this lack of correlation in the two first years of a presidential term. So, our empirical analysis is restricted to fiscal years (FY) 1986, 1987, 1990, 1991, 1994, 1995, 1998, 1999, 2002, 2006, 2007, and 2010. ${ }^{17} \mathrm{We}$ explain with an example why we restrict the sample to these years. As Table 1 shows, the budget for FY1986 is passed in 1985. Party leaders consider the level of party discipline and conflict that party members face in 1985; the level of conflict is measured using the results of the preceding presidential election (1984). In this case, the instrument (party discipline in 1983) cannot be the outcome of the level of conflict in the future (1984). ${ }^{18}$ In the two last years of a presidential term, lagged party discipline (our instrument) can be the outcome of the level of conflict (see for instance, FY1988 in Table 1).

\footnotetext{
${ }^{16}$ With a two-year lag of party discipline we drop freshman representatives from our sample. Lagging our explanatory variable an additional year would drop many more observations as it would require that a representative is in office during three Congresses. Given that a two-year lag already ensures that party discipline is based on roll call votes in a previous legislature, we do not think that a further time lag would improve our identification strategy.

${ }^{17}$ After each decennial census, the number of congressional districts per state is adjusted using the new population counts while ensuring that each state has at least one district. This process is known as reapportionment. Fiscal year 2003 is excluded from the sample because of congressional reapportionment.

${ }^{18}$ Note that US presidential elections take place in November, so they influence the behavior of legislators from the following year onwards.
} 
Table 1: Timing

\begin{tabular}{|c|c|c|c|}
\hline Fiscal year & Unity scores & Instrument & Presidential election \\
\hline 1986 & 1985 & 1983 & 1984 \\
\hline 1987 & 1986 & 1984 & 1984 \\
\hline 1988 & 1987 & 1985 & 1984 \\
\hline 1989 & 1988 & 1986 & 1984 \\
\hline 1990 & 1989 & 1987 & 1988 \\
\hline 1991 & 1990 & 1988 & 1988 \\
\hline 1992 & 1991 & 1989 & 1988 \\
\hline 1993 & 1992 & 1990 & 1988 \\
\hline 1994 & 1993 & 1991 & 1992 \\
\hline 1995 & 1994 & 1992 & 1992 \\
\hline 1996 & 1995 & 1993 & 1992 \\
\hline 1997 & 1996 & 1994 & 1992 \\
\hline 1998 & 1997 & 1995 & 1996 \\
\hline 1999 & 1998 & 1996 & 1996 \\
\hline 2000 & 1999 & 1997 & 1996 \\
\hline 2001 & 2000 & 1998 & 1996 \\
\hline 2002 & 2001 & 1999 & 2000 \\
\hline 2003 & 2002 & 2000 & 2000 \\
\hline 2004 & 2003 & 2001 & 2000 \\
\hline 2005 & 2004 & 2002 & 2000 \\
\hline 2006 & 2005 & 2003 & 2004 \\
\hline 2007 & 2006 & 2004 & 2004 \\
\hline 2008 & 2007 & 2005 & 2004 \\
\hline 2009 & 2008 & 2006 & 2004 \\
\hline 2010 & 2009 & 2007 & 2008 \\
\hline
\end{tabular}

Note: The figures in this table are to be read as follows: the Federal budget of FY1986 is passed in 1985. The unity scores of reference for FY1986 are those of year 1985 (instrumented with party unity scores in 1983). The presidential election outcomes of 1984 are used to measure the level of conflict that affects roll call votes (hence, unity scores) in 1985. 


\subsection{Data}

In this section, we provide further details on the variables mentioned above, including data sources and descriptive statistics.

\section{Discretionary spending}

Data on federal spending in congressional districts come from Dynes and Huber (2015) who assembled and cleaned the information provided by the Federal Assistance Awards Data System (FAADS) to examine another issue - namely, the affiliation with the President's party and the allocation of federal grants. This information accounts for approximately half of the federal budget. ${ }^{19}$ We focus our analysis on spending that is susceptible to political manipulation and follow previous work that classifies spending into high-variance and lowvariance programs based on their coefficient of variation (see, e.g., DeBacker 2011; Levitt and Snyder 1995; Dynes and Huber 2015; Berry, Burden and Howell 2010) ${ }^{20}$ High-variance spending is commonly associated with discretionary spending as it is usually not formulabased, and it tends to fund smaller programs that are more susceptible to targeting. All programs with a coefficient of variation greater than or equal to one are classified as porkbarrel spending. ${ }^{21}$ As mentioned previously, we restrict the analysis to new payments. Highvariation spending is arguably not a perfect measure of pork-barrel spending. However, pure distributive spending (i.e., earmarks in appropriation bills) is available only at the state level. Aggregating party discipline at that level would dismiss important information as there is a big divergence within states. Table A.1 in the Appendix shows the thirty largest programs, in terms of per capita spending, classified as high-variation programs.

The federal budget of a certain fiscal year is approved during the previous year. This means, for instance, that the pork-barrel expenditures of FY1995 were passed in 1994 by

\footnotetext{
${ }^{19}$ An alternative source, which contains most of the federal budget, is the Consolidated Federal Funds Report (CFFR). However, CFFR information is at the state level, and this does not allow us to identify with precision the recipients of federal funds.

${ }^{20}$ The coefficient of variation of each program is computed as follows. The standard deviation of the program's outlays across all districts in fiscal year $t$ is divided by the mean of its outlays across all districts in $t$ and then the mean of this across all years is computed. We exclude from this computation the districts that cross boundaries with state capitals. The reason is that spending allocated to state capitals is often spread among several districts. See Dynes and Huber (2015) for further details.

${ }^{21}$ This cutoff corresponds to a natural break observed at the lower end of a histogram of the coefficients of variation. The cutoff used by Dynes and Huber (2015) is 1.0, that used by Levitt and Snyder (1995) is 0.67, and that used by DeBacker (2011) is 1.2. As we show in the robustness section, moving this cutoff does not significantly change our results.
} 
legislators elected in the 1992 election. Federal spending in districts that include state capitals may be noisy, and for this reason we exclude these districts. We also disregard districts that, due to the early resignation or death of their representatives, have multiple occupants in a given year.

We collect population figures from the U.S. Census to express federal outlays in per-capita terms. Population at the district level is available only in decennial censuses (i.e., in 1980, 1990, and 2000). ${ }^{22}$ However, we can obtain an estimate of the district population using the state population estimates provided yearly by the U.S. Census and dividing them by the number of congressional districts in each year. ${ }^{23}$

\section{Party discipline}

We combine the data on federal spending with information on party discipline in the House of Representatives. Following the previous literature (e.g., Cantor and Herrnson 1997; Carson et al. 2010), we use party unity scores as an indicator of party loyalty in policy voting. This is our main explanatory variable (Unity). Party unity scores are available for each legislator in any given year. They are computed as the percentage of roll-call votes in which a representative voted "yea" or "nay" in agreement with her party when the majority of one party voted against the majority of the other party. ${ }^{24}$ The variable is standardized (mean of zero and standard deviation of one) such that coefficients associated to Unity can be interpreted as the effect of a one-standard deviation increase in party discipline.

Data on party unity scores are collected from the Congressional Quarterly Almanac. As shown in Figure 1, unity scores were, on average, around $70 \%$ in the early 1980s, but they increased significantly during the following decades and today total $90 \%$. The blue (red) horizontal lines in Figure 1 represent the years of a Democrat (Republican) majority.

\section{Conflict}

One of the main predictions of our theoretical model is that the effect of discipline on discretionary spending is larger the more intense the conflict of interest between the voters' preferences and the party line. Our main measure of conflict faced by a legislator is her

\footnotetext{
${ }^{22}$ http://www. census.gov/prod/www/decennial.html

${ }^{23}$ We can make this imputation because all congressional districts within a state are meant to have similar population sizes.

${ }^{24}$ Party discipline becomes especially visible in this context of confrontation. During the years 1986-2010, Democrats and Republicans voted against each other, on average, in $53 \%$ of all roll-call votes in the House of Representatives.
} 
Figure 1: Party discipline and party control in the House of Representatives

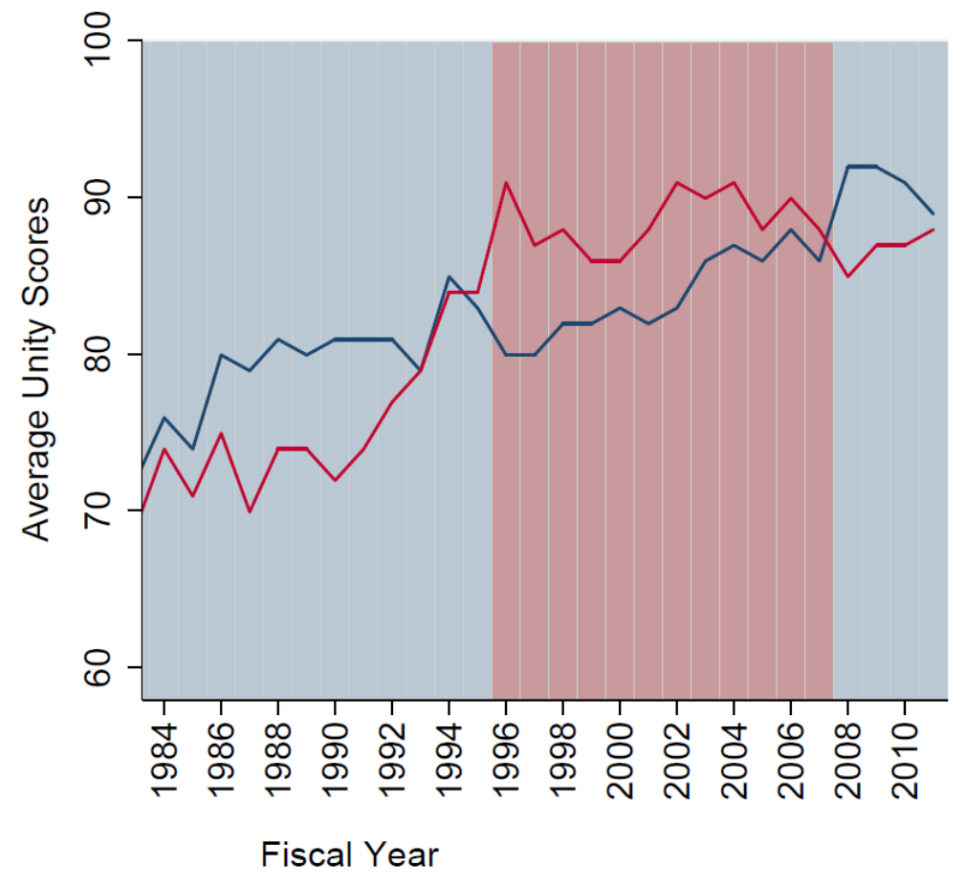

Notes: Congressional Quarterly Annual Report, January 2011. Blue (red) vertical bars correspond to Democratic (Republican) control. The solid blue lines represent the average unity score of the Democratic (Republican) party. (For interpretation of the references to color in this figure legend, the reader is referred to the web version of this article.)

district's vote share of a presidential candidate affiliated with the other party, i.e., the vote share of a Republican (Democratic) presidential candidate if the legislator is Democrat (Republican). This captures the degree of conflict and it is our preferred measure as it has some variation over time within districts. The variable is standardized (mean of zero and standard deviation of one). Data on presidential elections at the congressional district level comes from Jacobson (2015).

As a robustness check, we replace the continuous measure of conflict with a binary variable that equals one if a Republican legislator represents a district with an average presidential vote share of the Democratic party above the national average, or if a Democrat represents a district with an average presidential vote share of the Republican party above the national average. In other words, Conflict dummy identifies Republican representatives in liberalleaning districts and Democratic representatives in conservative-leaning districts. In our sample, $30 \%$ of legislators are in this setting. However, this figure varies considerably over 
the years: it drops from $40 \%$ initially to $21 \%$ in the last year of our sample.

Table A.2 in the Appendix summarizes the descriptive statistics of all variables included in our regressions.

\section{$5 \quad$ Empirical Results}

\subsection{Party Discipline and Discretionary Spending}

In Table 2 we show the effect of party discipline on discretionary spending estimating the regression in equation (5) using ordinary least squares (Panel A) and instrumental variables (Panel B). We include year and district fixed effects in all specifications. ${ }^{25}$ In column 3 we add region-by-year dummies for each of the four Census regions and in column 4 we include division-by-year dummies for the nine Census divisions. ${ }^{26}$ By including region-by-year and division-by-year effects, we can account to a certain extent for the shifts in voters' preferences that are specific to a certain area (e.g., some southern areas have become more conservative over the years, while the Northeast has become more liberal).

Estimates in Panel A of Table 2 indicate that a one-standard deviation increase in party discipline increases spending per capita by approximately $7 \%$. The estimates remain highly significant when we include political controls (column 2) and region- and division-by-year dummies (columns 3 and 4). If spending is directed towards less loyal party members in order to increase their discipline and this is effective, then the OLS estimates may underestimate the true effect of party discipline on spending. The results in Panel B suggest that this is the case and there is a large bias. The point estimate in column 2 shows that a one-standard deviation increase in unity scores raises pork-barrel spending by approximately $18 \%$. The results remain statistically significant across all specifications. Panel A of Table A.3 in the Appendix presents the first stage estimates. Lagged unity scores are highly relevant to explain current levels of discipline. The Kleibergen-Paap F-statistic in the first stage regression exceeds the Stock and Yogo critical value at $10 \%$ maximal IV relative bias. So we reject the hypothesis that the instrument is weak (Stock and Yogo, 2005).

Although party leaders of the House majority and the President's party may enjoy some legislative advantage, we do not find that loyal members of the House majority or President's party are rewarded to a greater extent. In Table A.4 in the Appendix, we show that the interaction terms Unity $\times$ Majority party and Unity $\times$ President ${ }^{\prime}$ party are statistically

\footnotetext{
${ }^{25}$ Recall that by "district" we mean district by census.

${ }^{26} \mathrm{See}$ regions and divisions established by the U.S. Census in https://www2.census.gov/geo/pdfs/ maps-data/maps/reference/us_regdiv.pdf
} 
Table 2: Party discipline and spending in U.S. congressional districts, 1986-2010.

\begin{tabular}{lcccc}
\hline & $(1)$ & $(2)$ & $(3)$ & $(4)$ \\
\hline \multirow{4}{*}{ Unity } & \multicolumn{4}{c}{ Panel A: OLS estimates } \\
& $0.065^{* * *}$ & $0.071^{* * *}$ & $0.078^{* * *}$ & $0.077^{* * *}$ \\
Constant & $(0.023)$ & $(0.025)$ & $(0.025)$ & $(0.025)$ \\
& $4.575^{* * *}$ & $4.687^{* * *}$ & $4.850^{* * *}$ & $4.887^{* * *}$ \\
$R^{2}$ & $(0.011)$ & $(0.058)$ & $(0.058)$ & $(0.060)$ \\
& 0.168 & 0.169 & 0.178 & 0.177 \\
& \multicolumn{4}{c}{} \\
Unity & & Panel B: IV estimates \\
& $0.138^{* * *}$ & $0.183^{* * *}$ & $0.186^{* * *}$ & $0.195^{* * *}$ \\
Constant & $(0.042)$ & $(0.052)$ & $(0.052)$ & $(0.055)$ \\
& $4.578^{* * *}$ & $4.727^{* * *}$ & $4.801^{* * *}$ & $4.806^{* * *}$ \\
& $(0.011)$ & $(0.062)$ & $(0.058)$ & $(0.061)$ \\
\hline Number of observations & 3,433 & 3,433 & 3,433 & 3,433 \\
District fixed effects & Yes & Yes & Yes & Yes \\
Year fixed effects & Yes & Yes & Yes & Yes \\
Political controls & No & Yes & Yes & Yes \\
Region-by-year effects & No & No & Yes & No \\
Division-by-year effects & No & No & No & Yes \\
\hline
\end{tabular}

Notes: Standard errors clustered at the district level in parentheses, $* * * \mathrm{p}<0.01,{ }^{* *} \mathrm{p}<0.05, * \mathrm{p}<0.1$. All specifications include year and districtby-census fixed effects. The dependent variable is the log of High-Variance (i.e., discretionary) spending per capita. Unity is standardized. State capitals, district-year observations with multiple occupants, and districts with freshman representatives are not included. Region-by-year effects interact four region dummies and division-by-year effects interact nine division dummies. The sample is restricted to the first two years of presidential terms. Political controls in columns 2-4 include President's party, Majority party, Republican, House is Republican $\times$ District has Republican partisanship, President is Republican $\times$ District has Republican partisanship, Winning presidential candidate's margin in state. 
insignificant.

\subsection{Heterogeneous Effects of Party Discipline}

The second prediction of our theoretical model is that a larger gap between constituents' and party's preferences increases the rewards for party discipline. In Table 3, we show the estimates of the heterogeneous effects as specified in equation (6). Panel A presents the OLS results as a baseline. However, we cannot make any causal interpretation as, in addition to the simultaneity bias, the inclusion of a potentially bad control (Conflict intensity) may bias the results further. The results in Panel A suggest that a one-standard deviation increase in Conflict intensity raises the rewards for party discipline by $2 \%$. Although the sign of the coefficient goes in the expected direction and the size is similar across the specifications, the effect is imprecisely estimated. The IV results in panel B provide more robust estimates and suggest that increasing Conflict intensity by one standard deviation raises the rewards for party discipline by about $5 \%$. This heterogeneous effect is statistically significant in all the specifications except column 4 where we include division-by-year fixed effects. However, the point estimate is the same as in column 3, which suggests that the lack of significant effects is only due to the lack of within-variation of Conflict intensity. Panel B of Table A.3 in the Appendix presents the first stage estimates.

\subsection{Additional Results and Robustness}

The estimates reported in the previous sections provide clear evidence that party loyalty is associated with larger amounts of discretionary spending allocated to the corresponding districts. Moreover, this effect is more pronounced the larger the conflict between the constituency's interests and the party line. In what follows, we run several robustness checks to validate our previous findings. All results correspond to the second stage of two-stage least square regressions.

\section{Potential confounders}

As a robustness check, we investigate whether the heterogeneous effects of party loyalty arise because of the different levels of conflict intensity and not because of other factors that are correlated with such conflict. To test this, we include in equation (6) interaction terms between the variable Unity and different potential confounding factors that are correlated with the variable Conflict intensity and may impact the allocation of public spending. The results are presented in Table 4. A representative elected in a district with low support for her 
Table 3: Party discipline and federal spending: heterogeneous effects.

\begin{tabular}{|c|c|c|c|c|}
\hline & (1) & (2) & $(3)$ & $(4)$ \\
\hline & \multicolumn{4}{|c|}{ Panel A: OLS estimates } \\
\hline \multirow[t]{2}{*}{ Unity } & $0.059^{* *}$ & $0.062^{* *}$ & $0.071^{* * *}$ & $0.071^{* * *}$ \\
\hline & $(0.024)$ & $(0.025)$ & $(0.025)$ & $(0.025)$ \\
\hline \multirow[t]{2}{*}{ Unity $\times$ Conflict intensity } & 0.016 & 0.024 & 0.017 & 0.015 \\
\hline & $(0.018)$ & $(0.020)$ & $(0.019)$ & $(0.020)$ \\
\hline \multirow[t]{2}{*}{ Conflict intensity } & -0.006 & -0.013 & -0.015 & -0.021 \\
\hline & $(0.039)$ & $(0.045)$ & $(0.045)$ & $(0.047)$ \\
\hline \multirow[t]{2}{*}{ Constant } & $4.581^{* * *}$ & $4.703^{* * *}$ & $4.862^{* * *}$ & $4.902^{* * *}$ \\
\hline & $(0.013)$ & $(0.062)$ & $(0.062)$ & $(0.066)$ \\
\hline \multirow[t]{2}{*}{$R^{2}$} & 0.168 & 0.169 & 0.178 & 0.177 \\
\hline & \multicolumn{4}{|c|}{ Panel B: IV estimates } \\
\hline \multirow[t]{2}{*}{ Unity } & $0.110^{* *}$ & $0.141^{* *}$ & $0.157^{* * *}$ & $0.163^{* * *}$ \\
\hline & $(0.045)$ & $(0.056)$ & $(0.057)$ & $(0.060)$ \\
\hline \multirow[t]{2}{*}{ Unity $\times$ Conflict intensity } & $0.053^{* *}$ & $0.065^{* *}$ & $0.051^{*}$ & 0.051 \\
\hline & $(0.027)$ & $(0.030)$ & $(0.030)$ & $(0.031)$ \\
\hline \multirow[t]{2}{*}{ Conflict intensity } & 0.024 & 0.027 & 0.022 & 0.017 \\
\hline & $(0.041)$ & $(0.050)$ & $(0.050)$ & $(0.052)$ \\
\hline \multirow[t]{2}{*}{ Constant } & $4.598^{* * *}$ & $4.748^{* * *}$ & $4.745^{* * *}$ & $4.829^{* * *}$ \\
\hline & $(0.016)$ & $(0.064)$ & $(0.066)$ & $(0.065)$ \\
\hline Number of observations & 3,433 & 3,433 & 3,433 & 3,433 \\
\hline District fixed effects & Yes & Yes & Yes & Yes \\
\hline Year fixed effects & Yes & Yes & Yes & Yes \\
\hline Political controls & No & Yes & Yes & Yes \\
\hline Region-by-year effects & No & No & Yes & No \\
\hline Division-by-year effects & No & No & No & Yes \\
\hline
\end{tabular}

Notes: Standard errors clustered at the district level in parentheses, ${ }^{* * *} \mathrm{p}<0.01$, ${ }^{*} \mathrm{p}<0.05, * \mathrm{p}<0.1$. All specifications include year and district-by-census fixed effects. The dependent variable is the log of High-Variance spending per capita. Unity and Conflict intensity are standardized variables. Conflict intensity is the presidential vote share of the Democratic party if the district representative is Republican and the presidential vote share of the Republican party if the district representative is Democrat. State capitals, district-year observations with multiple occupants, and districts with freshman representatives are not included. Political controls as in Table 2. 
party is likely to have faced intense electoral competition and therefore to have been elected in a close election. Thus, in columns 1 and 2 we add an interaction term between party discipline and a dummy for close congressional elections (vote margin below 5\%). Moreover, in columns 3 and 4 we include an interaction term between party unity and the legislator's vote margin in the last congressional election. We do so to account for the legislator's popularity or valence, which may affect its capacity to secure funds. Finally, Republican-leaning districts are less likely to elect a representative affiliated with the Democratic party. To control for this fact, in columns 5 and 6 we add an interaction term between party unity and a district's Republican tendency. ${ }^{27}$

The only interaction that is statistically significant in Table 4 is that of Unity $\times$ Vote margin. If the vote margin captures to a certain extent the valence of legislators, then the results in columns 3 and 4 suggest that more competent legislators extract more rewards. Importantly, our interaction effect of interest Unity $\times$ Conflict intensity remains statistically significant in all specifications except in column 6 (where it is imprecisely estimated), and its magnitude is similar to the previous results presented in Table 3.

\section{Alternative measures of key variables}

As an additional robustness check to validate our previous findings, we test the sensitivity of the results to the definition of discretionary spending. We apply two additional thresholds to classify spending into low- and high-variance programs. The estimates are presented in Table A.5 of the Appendix. In columns 1-3 we set the threshold at 1.12 (as in DeBacker, 2011) and in columns $4-5$ at 0.67 (as in Levitt and Snyder, 1995). The results are robust to the change in the definition of the outcome variable: the sign of the coefficient of interest remains the same (positive) and the magnitude of the effect is similar to our previous estimates.

As a placebo test, we estimate the effect of party discipline on low-variance spending. This type of spending is usually formula-based and thus is more difficult to manipulate. Therefore, we expect no significant relationship. The results in Table A.6 of the Appendix reveal that, indeed, party discipline plays no role in the distribution of non-discretionary spending.

Finally, we examine whether the heterogeneous effects of party discipline are robust to a different definition of conflict. We replace our continuous measure of conflict with a dummy variable that equals one if a Republican legislator represents a liberal-leaning district or a Democratic legislator represents a conservative-leaning district. Table A.7 in the Appendix

\footnotetext{
${ }^{27}$ This variable measures the Republican orientation of congressional districts based on average presidential election returns. This variable has no variation over time within district-by-census units. The original variable (from Dynes and Huber, 2015) ranges from -1 to 1 but in our analysis it is a standardized variable.
} 
Table 4: Potential confounding factors. IV estimates.

\begin{tabular}{|c|c|c|c|c|c|c|}
\hline & (1) & $(2)$ & (3) & (4) & $(5)$ & $(6)$ \\
\hline \multirow[t]{2}{*}{ Unity } & $0.109 * *$ & $0.157^{* * *}$ & $0.107^{* *}$ & $0.156^{* * *}$ & $0.110^{* *}$ & $0.157^{* * *}$ \\
\hline & $(0.045)$ & $(0.057)$ & $(0.045)$ & $(0.057)$ & $(0.045)$ & $(0.057)$ \\
\hline \multirow[t]{2}{*}{ Unity $\times$ Conflict intensity } & $0.053^{* *}$ & $0.051^{*}$ & $0.058^{* *}$ & $0.057^{*}$ & $0.062^{* *}$ & 0.052 \\
\hline & $(0.027)$ & $(0.030)$ & $(0.027)$ & $(0.030)$ & $(0.030)$ & $(0.033)$ \\
\hline \multirow[t]{2}{*}{ Conflict intensity } & 0.008 & 0.008 & 0.032 & 0.029 & 0.029 & 0.023 \\
\hline & $(0.041)$ & $(0.050)$ & $(0.043)$ & $(0.051)$ & $(0.042)$ & $(0.051)$ \\
\hline \multirow[t]{2}{*}{ Unity $\times$ Close election } & 0.023 & -0.005 & & & & \\
\hline & $(0.081)$ & $(0.080)$ & & & & \\
\hline \multirow[t]{2}{*}{ Close election } & $0.222^{* *}$ & $0.207^{* *}$ & & & & \\
\hline & $(0.103)$ & $(0.096)$ & & & & \\
\hline \multirow[t]{2}{*}{ Unity $\times$ Vote margin } & & & $0.049^{* * *}$ & $0.044^{* *}$ & & \\
\hline & & & $(0.018)$ & $(0.018)$ & & \\
\hline \multicolumn{7}{|l|}{ Vote margin } \\
\hline \multirow[t]{2}{*}{ Unity $\times$ District Republican tendency } & & & & & -0.026 & -0.004 \\
\hline & & & & & $(0.050)$ & $(0.051)$ \\
\hline \multirow[t]{2}{*}{ Constant } & $4.593^{* * *}$ & $4.779^{* * *}$ & $4.592^{* * *}$ & $4.819^{* * *}$ & $4.597^{* * *}$ & $4.793^{* * *}$ \\
\hline & $(0.016)$ & $(0.060)$ & $(0.016)$ & $(0.062)$ & $(0.016)$ & $(0.067)$ \\
\hline Number of observations & 3,433 & 3,433 & 3,433 & 3,433 & 3,433 & 3,433 \\
\hline District fixed effects & Yes & Yes & Yes & Yes & Yes & Yes \\
\hline Year fixed effects & Yes & Yes & Yes & Yes & Yes & Yes \\
\hline Political controls & No & Yes & No & Yes & No & Yes \\
\hline Region-by-year effects & No & Yes & No & Yes & No & Yes \\
\hline
\end{tabular}

Notes: Standard errors clustered at the district level in parentheses, ${ }^{* * *} \mathrm{p}<0.01,{ }^{* *} \mathrm{p}<0.05,{ }^{*} \mathrm{p}<0.1$. All specifications include year and district-by-census fixed effects. The dependent variable is the log of HighVariance spending per capita. Unity, Conflict intensity, Vote margin, and District Republican tendency are standardized variables. Conflict intensity is the presidential vote share of the Democratic party if the district representative is Republican and the presidential vote share of the Republican party if the district representative is Democrat. State capitals, district-year observations with multiple occupants, and districts with freshman representatives are not included. Political controls as in previous tables. 
summarizes the results. The point estimates in column 1 indicate that increasing party unity by one standard deviation raises discretionary spending per capita by $9.9 \%$ in districts where legislators face no conflict of interest. This effect nearly doubles when such conflict exists. This result remains significant when we include a set of political controls (column 2). When we add region-by-year and division-by-year effects (columns 3 and 4) the point estimate of the interaction term is less precisely estimated, most probably because this strategy removes considerable variation.

\section{Conclusions}

In this paper, we investigate theoretically and empirically the impact of party discipline on the distribution of discretionary spending. In our context, party discipline refers to the ability of party leaders to ensure that party members support the party line. Following the party line might be electorally costly for legislators as it may go against their constituents' interests. In these instances, the party leaders might have to reward the legislators. One of such reward is discretionary spending targeted to the legislators' constituencies. Discretionary grants are often viewed as unproductive federal spending used to fund targeted projects, which are sometimes referred to as "bridges to nowhere." However, the party leaders have certain levels of power to allocate discretionary grants and thus can use them to influence legislators to vote along the party line.

We develop a theoretical model in which a politician faces a conflict between the constituents' preferences and the party's interests. Following the party line (i.e., being loyal) is electorally costly for the politician. To offset electoral punishment, the party leader rewards the politician's loyalty with discretionary spending allocated to her constituency. Our model predicts that party discipline leads to larger amounts of targeted spending. Moreover, this effect is more pronounced the larger the conflict between the party's interests and the voters' preferences.

We test the predictions of our model using district-level data on U.S. federal spending and party discipline in the House of Representatives over the 1986-2010 period. Our findings suggest that a one-standard deviation increase in party discipline raises discretionary spending by $18 \%$ on average. We also find that increasing conflict intensity by one standard deviation raises the rewards for discipline by about 5\%. These findings are in line with our theoretical model, according to which representatives face a tougher trade-off in those districts were constituents' and party's preferences differ the most and thus demand higher rewards for supporting the party line. 
From a more general perspective, our study emphasizes the impacts of party loyalty on federal spending while the existing literature has mainly focused on the political consequences of party discipline. This emphasis allows us to disclose additional sources of uneven distribution of federal grants, namely, representatives' loyalty to party lines and conflict between constituents' and party's interests. Therefore, our findings complement the existing literature and suggest that various studies on federal spending may benefit from taking party discipline and conflict intensity into account.

\section{References}

Albouy, D. 2013. "Partisan Representation in Congress and the Geographic Distribution of Federal Funds." Review of Economics and Statistics 95(1):127-141.

Arulampalam, W., S. Dasgupta, A. Dhillon and B. Dutta. 2009. "Electoral Goals and CenterState Transfers: a Theoretical Model and Empirical Evidence from India." Journal of Development Economics 88:103-119.

Ashworth, S. and E. Bueno de Mesquita. 2004. "Endogenous Party Discipline with Variable Electoral and Legislative Institutions." Institute of Governmental Studies Working Paper 2004-7.

Atlas, C., T. Gilligan, R. Hendershott and M. Zupan. 1995. "Slicing the federal government net spending pie: who wins, who loses, and why." American Economic Review 85:624-9.

Barber, M., B. Canes-Wrone and J.-F. Godbout. 2014. Party Loyalty and Campaign Contributions. In Paper presented at the European Political Science Association Annual Meeting, 21 June 2014.

Berry, C. R., B. C. Burden and W. G. Howell. 2010. "The President and the Distribution of Federal Spending." American Political Science Review 104(4):783-799.

Brollo, F. and T. Nannicini. 2012. "Tying your Enemy's Hands in Close Races: the Politics of Federal Transfers in Brazil.” American Political Science Review 106:742-761.

Cann, D. M. and A.H Sidman. 2011. "Exchange Theory, Political Parties, and the Allocation of Federal Distributive Benefits in the House of Representatives." The Journal of Politics 73(4):1128-1141.

Cantor, D. M and P. S. Herrnson. 1997. "Party Campaign Activity and Party Unity in the U.S. House of Representatives." Legislative Studies Quarterly 22(3):393-415. 
Carson, J. L., G. Koger, M. J. Lebo and E. Young. 2010. "The Electoral Costs of Party Loyalty in Congress." American Journal of Political Science 54(3):598-616.

Castanheira, M. and B. S. Y. Crutzen. 2010. "Comparative Politics with Endogenous IntraParty Discipline." mimeo .

Colomer, J. M. 2005. "Policy Making in Divided Government: A Pivotal Actors Model with Party Discipline." Public Choice 125:247-269.

Cox, G. W. and M.D. McCubbins. 1993. Legislative Leviathan: Party Government in the House. Berkeley: University of California Press.

DeBacker, J. 2011. "The Price of Pork: The Seniority Trap in the U.S. House." Journal of Public Economics 95:63-78.

Diermeier, D. and T.J. Feddersen. 1998a. "Cohesion in Legislatures and the Vote of Confidence Procedure." American Political Science Review 92:611-621.

Diermeier, D. and T.J. Feddersen. 1998b. "Comparing Constitutions: Cohesion and Distribution in Legislatures." European Economic Review 42:665-672.

Dixit, A. and J. Londregan. 1996. "The determinants of success of special interests in redistributive politics." Journal of Politics 58:1132-55.

Dynes, A. M. and G. A. Huber. 2015. "Partisanship and the Allocation of Federal Spending: Do Same-Party Legislators or Voters Benefit from Shared Party Affiliation with the President and the House Major." American Political Science Review 109(1):172-186.

Eguia, J. X. 2011. "Voting Blocs, Party Discipline and Party Formation." Games and Economic Behavior 73:111-135.

Ferreira, E. and J. Gyourko. 2009. "Do political parties matter? Evidence from US cities." Quarterly Journal of Economics 124(1):399-422.

Golden, M. and B. Min. 2013. "Distributive Politics around the World." Annual Review of Political Science 16:73-99.

Grossman, G. M. and E. Helpman. 2008. Institutions and Economic Performance. Cambridge: Harvard University Press chapter Party Discipline and Pork-Barrel Politics. 
Heller, W. B. and C. Mershon. 2008. "Dealing in Discipline: Party Switching and Legislative Voting in the Italian Chamber of Deputies, 1988-2000." American Journal of Political Science 52:910-925.

Iaryczower, M. 2008. "Contestable Leadership: Party Leaders as Principals and Agents." Quarterly Journal of Political Science 3:203-225.

Jacobson, G. C. 2015. "It's Nothing Personal: The Decline of the Incumbency Advantage in US House Elections." Journal of Politics 77:861-873.

Knight, B. 2004. "Parochial Interests and the Centralized Provision of Local Public Goods: Evidence from Congressional Voting on Transportation Projects." Journal of Public Economics 88(3):845-866.

Knight, B. 2008. "Legislative Representation, Bargaining Power and the Distribution of Federal Funds: Evidence from the US Congress." The Economic Journal 118:1785-1803.

Krehbiel, K. 2000. "Party Discipline and Measures of Partisanship." American Journal of Political Science 44:212-227.

Levitt, S. D. and J.M. Snyder. 1995. "Political Parties and the Distribution of Federal Outlays." American Journal of Political Science 39(4):958-80.

Lindbeck, A. and J. W. Weibull. 1987. "Balanced-Budget Redistribution as the Outcome of Political Competition." Public Choice 52:237-297.

McCarty, N., K. T. Poole and H. Rosenthal. 2001. "The Hunt for Party Discipline in Congress." American Political Science Review 95:673-687.

McGillivray, F. 1997. "Party Discipline as a Determinant of the Endogenous Formation of Tariffs." American Journal of Political Science 41:584-607.

Patty, John W. 2008. "Equilibrium Party Government." American Journal of Political Science 52:636-655.

Pearson, K. 2008. Why Not Parties?: Party Effects in the United States Senate. Chicago: University of Chicago Press chapter Party Loyalty and Discipline in the Individualistic Senate, pp. 100-120.

Primo, D. M. and J. M. Snyder. 2010. "Party Strength, the Personal Vote, and Government Spending." American Journal of Political Science 54(2):354-370. 
Rohde, D. 1991. Parties and Leaders in the Postreform House. Chicago: University of Chicago Press.

Shi, M. and J. Svensson. 2016. "Political Budget Cycles: Do they Differ Across Countries and Why?" Journal of Public Economics 90:1367-1389.

Snyder, J. M. Jr. and M.M Ting. 2002. "An Informational Rationale for Political Parties." American Journal of Political Science 46:90-110.

Snyder, J. M. Jr. and T. Groseclose. 2000. "Estimating Party Influence in Congressional Roll-Call Voting." American Journal of Political Science 44:193-211.

Stock, J. and M. Yogo. 2005. Testing for Weak Instruments in Linear IV Regression. Cambridge University Press pp. 80-108.

Stokes, S., T. Dunning, M. Nazareno and V. Brusco. 2013. Brokers, Voters and Clientelism: The Puzzle of Distributive Politics. Cambridge University Press.

Volden, C. and E. Bergman. 2006. "How Strong Should Our Party Be? Party Member Preferences Over Party Cohesion." Legislative Studies Quarterly XXXI:71-104.

Zelizer, J. 2014. "Is There Anything Wrong with a Littler Pork Barrel Spending?" CNN http://edition.cnn.com/2014/05/12/opinion/zelizer-the-case-for-earmarks/.

Zeller, B. 1954. American State Legislatures. NewYork: Crowell. 


\section{Appendix}

\section{A Additional tables}

Table A.1: Largest high-variation programs in FAADS.

\begin{tabular}{|c|c|c|}
\hline $\begin{array}{l}\text { Program } \\
\text { code }\end{array}$ & Program name & $\begin{array}{c}\text { Mean per capita } \\
\text { spending }\end{array}$ \\
\hline 10.551 & Food stamp program & 682.85 \\
\hline 81.13 & Carbon capture and storage-FutureGen 2.0 & 443.23 \\
\hline 93.784 & Federal reimbursement of emergency health services furnished to undocumented & 181.69 \\
\hline 15.DAW & Southern Nevada public land management act & 171.26 \\
\hline 20.319 & High-speed rail corridors and intercity psngr rail svc-cap. assist grants & 154.37 \\
\hline 84.010 & Title I grants to local education agencies & 62.47 \\
\hline 14.871 & Section 8 housing choice vouchers & 52.08 \\
\hline 20.804 & Operating-differential subsidies & 47.72 \\
\hline 10.561 & State administrative matching grants for food stamp program & 39.12 \\
\hline 11.553 & Special projects & 37.49 \\
\hline 84.027 & Special education-grants to states & 33.73 \\
\hline 84.295 & Ready to learn television & 33.67 \\
\hline 12.RED & Assistance to the red cross via DDSW & 33.63 \\
\hline 20.205 & Highway planning and construction & 26.13 \\
\hline 93.658 & Foster care title IV-E & 20.93 \\
\hline 14.311 & Single family property disposition & 20.72 \\
\hline 11.477 & Fisheries disaster relief & 20.30 \\
\hline 81.131 & Expand and extend clean coal power initiative & 18.85 \\
\hline 11.557 & Broadband technology opportunities program (BTOP) & 18.75 \\
\hline 10.787 & Broadband initiatives program - recovery & 16.78 \\
\hline 14.195 & Section 8 housing assistance payments program-special allocations & 16.56 \\
\hline 15.235 & Southern Nevada public land management & 16.43 \\
\hline 93.667 & Social services block grant & 16.37 \\
\hline 12.DAC & Women in services memorial foundation & 16.23 \\
\hline 97.024 & Emergency food and shelter national board program & 16.02 \\
\hline 11.617 & Congressionally identified projects & 15.82 \\
\hline 14.256 & Neighborhood stabilization program (recovery act funded) & 15.53 \\
\hline 19.4 & Educational exchange-graduate students (Fulbright program) & 14.67 \\
\hline 15.531 & Part F - discretionary grants & 14.65 \\
\hline
\end{tabular}


Table A.2: Descriptive statistics.

\begin{tabular}{lcccc}
\hline Variable & Mean & St.Dev. & Min & Max \\
\hline Log(High-variation spending per capita) & 4.507 & 1.153 & -0.708 & 8.513 \\
Log(Low-variation spending per capita) & 1.054 & 2.34 & -10.581 & 5.229 \\
Party unity & 0 & 1 & -5.735 & 1.059 \\
Conflict intensity & 0 & 1 & -3.082 & 2.704 \\
Conflict dummy & 0.299 & 0.458 & 0 & 1 \\
President's party & 0.473 & 0.499 & 0 & 1 \\
Majority party & 0.572 & 0.495 & 0 & 1 \\
Republican & 0.447 & 0.497 & 0 & 1 \\
Repub. President $\times$ District Republican tendency & -0.006 & 0.108 & -0.515 & 0.293 \\
Repub. House $\times$ District Republican tendency & -0.004 & 0.092 & -0.413 & 0.293 \\
District Republican tendency & 0 & 1 & -3.687 & 2.178 \\
Close election & 0.027 & 0.162 & 0 & 1 \\
Vote margin & 0 & 1 & -1.53 & 1.985 \\
\hline
\end{tabular}


Table A.3: First stage of two-stage least square regressions.

\begin{tabular}{lcccc}
\hline & $(1)$ & $(2)$ & $(3)$ & $(4)$ \\
\hline \multirow{4}{*}{ Pagged unity } & $0.562^{* * *}$ & $0.533^{* * *}$ & $0.534^{* * *}$ & $0.524^{* * *}$ \\
& $(0.042)$ & $(0.046)$ & $(0.047)$ & $(0.046)$ \\
Kleibergen-Paap F-stat & 189.34 & 134.04 & 131.29 & 125.64 \\
& \multicolumn{5}{c}{ Panel B: Heterogeneous effects } \\
Lagged unity & $0.590^{* * *}$ & $0.565^{* * *}$ & $0.558^{* * *}$ & $0.546^{* * *}$ \\
& $(0.046)$ & $(0.051)$ & $(0.050)$ & $(0.050)$ \\
Kleibergen-Paap F-stat & 86.89 & 62.07 & 61.37 & 58.54 \\
\hline Number of observations & 3,433 & 3,433 & 3,433 & 3,433 \\
District fixed effects & Yes & Yes & Yes & Yes \\
Year fixed effects & Yes & Yes & Yes & Yes \\
Political controls & No & Yes & Yes & Yes \\
Region-by-year effects & No & No & Yes & No \\
Division-by-year effects & No & No & No & Yes \\
\hline
\end{tabular}

Notes: Standard errors clustered at the district level in parentheses, ${ }^{* * *} \mathrm{p}<0.01$, ${ }^{* *} \mathrm{p}<0.05,{ }^{*} \mathrm{p}<0.1$. All specifications include year and district-by-census fixed effects. State capitals, district-year observations with multiple occupants, and districts with freshman representatives are not included. The point estimates in panels A and B correspond to the first stages of the 2SLS regressions in Panel B of tables 2 and 3, respectively. The instrument (lagged unity) is a two-year lag of party unity scores. 
Table A.4: Does partisanship influence the rewards for party discipline?

\begin{tabular}{|c|c|c|c|c|c|c|}
\hline & (1) & $(2)$ & $(3)$ & $(4)$ & $(5)$ & $(6)$ \\
\hline & \multicolumn{6}{|c|}{ Panel A: OLS estimates } \\
\hline \multirow[t]{2}{*}{ Unity } & $0.063^{* *}$ & $0.073^{* * *}$ & $0.075^{* * *}$ & $0.052^{*}$ & $0.061^{* *}$ & $0.062^{* *}$ \\
\hline & $(0.026)$ & $(0.026)$ & $(0.027)$ & $(0.030)$ & $(0.030)$ & $(0.031)$ \\
\hline \multirow[t]{2}{*}{ Unity $\times$ Majority party } & 0.018 & 0.012 & 0.005 & & & \\
\hline & $(0.033)$ & $(0.034)$ & $(0.034)$ & & & \\
\hline \multirow[t]{2}{*}{ Unity $\times$ President's party } & & & & 0.039 & 0.033 & 0.031 \\
\hline & & & & $(0.029)$ & $(0.029)$ & $(0.030)$ \\
\hline \multirow[t]{2}{*}{ Majority party } & -0.024 & -0.023 & -0.031 & -0.038 & -0.033 & -0.039 \\
\hline & $(0.038)$ & $(0.038)$ & $(0.040)$ & $(0.040)$ & $(0.039)$ & $(0.042)$ \\
\hline \multirow[t]{2}{*}{ President's party } & -0.015 & -0.016 & -0.009 & -0.002 & -0.007 & -0.002 \\
\hline & $(0.033)$ & $(0.032)$ & $(0.033)$ & $(0.034)$ & $(0.033)$ & $(0.034)$ \\
\hline \multirow[t]{3}{*}{ Constant } & $4.687^{* * *}$ & $4.849^{* * *}$ & $4.887^{* * *}$ & $4.685^{* * *}$ & $4.848^{* * *}$ & $4.884^{* * *}$ \\
\hline & $(0.057)$ & $(0.057)$ & $(0.060)$ & $(0.058)$ & $(0.058)$ & $(0.060)$ \\
\hline & \multicolumn{6}{|c|}{ Panel B: IV estimates } \\
\hline \multirow[t]{2}{*}{ Unity } & $0.161^{* * *}$ & $0.174^{* * *}$ & $0.183^{* * *}$ & $0.190^{* * *}$ & $0.193^{* * *}$ & $0.203^{* * *}$ \\
\hline & $(0.052)$ & $(0.054)$ & $(0.056)$ & $(0.058)$ & $(0.059)$ & $(0.062)$ \\
\hline \multirow[t]{2}{*}{ Unity $\times$ Majority party } & 0.061 & 0.035 & 0.034 & & & \\
\hline & $(0.051)$ & $(0.054)$ & $(0.057)$ & & & \\
\hline \multirow[t]{2}{*}{ Unity $\times$ President's party } & & & & -0.016 & -0.017 & -0.019 \\
\hline & & & & $(0.044)$ & $(0.044)$ & $(0.046)$ \\
\hline \multirow[t]{2}{*}{ Majority party } & -0.061 & -0.065 & $-0.077^{*}$ & -0.071 & -0.068 & -0.078 \\
\hline & $(0.044)$ & $(0.043)$ & $(0.045)$ & $(0.046)$ & $(0.044)$ & $(0.048)$ \\
\hline \multirow[t]{2}{*}{ President's party } & -0.032 & -0.029 & -0.024 & -0.018 & -0.021 & -0.017 \\
\hline & $(0.035)$ & $(0.034)$ & $(0.036)$ & $(0.036)$ & $(0.035)$ & $(0.036)$ \\
\hline \multirow[t]{2}{*}{ Constant } & $4.727^{* * *}$ & $4.770^{* * *}$ & $4.809^{* * *}$ & $4.728^{* * *}$ & $4.801^{* * *}$ & $4.808^{* * *}$ \\
\hline & $(0.062)$ & $(0.058)$ & $(0.061)$ & $(0.062)$ & $(0.058)$ & $(0.060)$ \\
\hline Number of observations & 3,433 & 3,433 & 3,433 & 3,433 & 3,433 & 3,433 \\
\hline District fixed effects & Yes & Yes & Yes & Yes & Yes & Yes \\
\hline Year fixed effects & Yes & Yes & Yes & Yes & Yes & Yes \\
\hline Political controls & Yes & Yes & Yes & Yes & Yes & Yes \\
\hline Region-by-year effects & No & Yes & No & No & Yes & No \\
\hline Division-by-year effects & No & No & Yes & No & No & Yes \\
\hline
\end{tabular}

Notes: Standard errors clustered at the district level in parentheses, ${ }^{* * *} \mathrm{p}<0.01,{ }^{* *} \mathrm{p}<0.05,{ }^{*} \mathrm{p}<0.1$. All specifications include year and district-by-census fixed effects. The dependent variable is the $\log$ of High-Variance spending per capita. Unity is a standardized variable. Majority party and President's party are dummy variables that indicate whether the legislator is affiliated with the House majority party or President's party, respectively. Sample restrictions and political controls as in table 2 . 
Table A.5: Alternative measures of discretionary spending.

\begin{tabular}{|c|c|c|c|c|c|c|}
\hline & $(1)$ & $(2)$ & (3) & $(4)$ & $(5)$ & (6) \\
\hline & \multicolumn{3}{|c|}{ Threshold $=1.12$} & \multicolumn{3}{|c|}{ Threshold $=0.67$} \\
\hline & \multicolumn{6}{|c|}{ Panel A: Homogeneous effects } \\
\hline Unity & $\begin{array}{c}0.172^{* * *} \\
(0.057)\end{array}$ & $\begin{array}{c}0.166^{* * *} \\
(0.056)\end{array}$ & $\begin{array}{c}0.177^{* * *} \\
(0.059)\end{array}$ & $\begin{array}{c}0.132^{* * *} \\
(0.043)\end{array}$ & $\begin{array}{c}0.129^{* * *} \\
(0.043)\end{array}$ & $\begin{array}{c}0.138^{* * *} \\
(0.046)\end{array}$ \\
\hline Constant & $\begin{array}{c}4.455^{* * *} \\
(0.072)\end{array}$ & $\begin{array}{c}4.490^{* * *} \\
(0.068)\end{array}$ & $\begin{array}{c}4.482^{* * *} \\
(0.069)\end{array}$ & $\begin{array}{c}4.871^{* * *} \\
(0.057)\end{array}$ & $\begin{array}{c}4.963^{* * *} \\
(0.055)\end{array}$ & $\begin{array}{c}4.965^{* * *} \\
(0.056)\end{array}$ \\
\hline & \multicolumn{6}{|c|}{ Panel B: Heterogeneous effects } \\
\hline Unity & $\begin{array}{l}0.108^{*} \\
(0.060)\end{array}$ & $\begin{array}{c}0.124^{* *} \\
(0.060)\end{array}$ & $\begin{array}{c}0.131^{* *} \\
(0.062)\end{array}$ & $\begin{array}{l}0.085^{*} \\
(0.047)\end{array}$ & $\begin{array}{c}0.098^{* *} \\
(0.048)\end{array}$ & $\begin{array}{c}0.107^{* *} \\
(0.051)\end{array}$ \\
\hline Unity $\times$ Conflict intensity & $\begin{array}{c}0.100^{* * *} \\
(0.033)\end{array}$ & $\begin{array}{c}0.073^{* *} \\
(0.033)\end{array}$ & $\begin{array}{c}0.073^{* *} \\
(0.034)\end{array}$ & $\begin{array}{c}0.062^{* *} \\
(0.025)\end{array}$ & $\begin{array}{c}0.043^{*} \\
(0.024)\end{array}$ & $\begin{array}{c}0.040 \\
(0.025)\end{array}$ \\
\hline Conflict intensity & $\begin{array}{c}0.041 \\
(0.058)\end{array}$ & $\begin{array}{c}0.031 \\
(0.056)\end{array}$ & $\begin{array}{c}0.024 \\
(0.058)\end{array}$ & $\begin{array}{c}0.008 \\
(0.046)\end{array}$ & $\begin{array}{c}0.002 \\
(0.046)\end{array}$ & $\begin{array}{l}-0.003 \\
(0.048)\end{array}$ \\
\hline Constant & $\begin{array}{c}4.486^{* * *} \\
(0.074)\end{array}$ & $\begin{array}{c}4.553^{* * *} \\
(0.071)\end{array}$ & $\begin{array}{c}4.504^{* * *} \\
(0.076)\end{array}$ & $\begin{array}{c}4.893^{* * *} \\
(0.060)\end{array}$ & $\begin{array}{c}4.982^{* * *} \\
(0.058)\end{array}$ & $\begin{array}{c}5.000^{* * *} \\
(0.060)\end{array}$ \\
\hline Number of observations & 3,433 & 3,433 & 3,433 & 3,433 & 3,433 & 3,433 \\
\hline District fixed effects & Yes & Yes & Yes & Yes & Yes & Yes \\
\hline Year fixed effects & Yes & Yes & Yes & Yes & Yes & Yes \\
\hline Political controls & Yes & Yes & Yes & Yes & Yes & Yes \\
\hline Region-by-year effects & No & Yes & No & No & Yes & No \\
\hline Division-by-year effects & No & No & Yes & No & No & Yes \\
\hline
\end{tabular}

Notes: Standard errors clustered at the district level in parentheses, ${ }^{* * *} \mathrm{p}<0.01,{ }^{* *} \mathrm{p}<0.05,{ }^{*} \mathrm{p}<0.1$. All specifications include year and district-by-census fixed effects. The dependent variable is the log of HighVariance spending per capita. In columns 1-3, the threshold to classify high-variance spending is 1.12 , while in columns 4-6 it is 0.67. Unity and Conflict intensity are standardized variables. Conflict intensity is the presidential vote share of the Democratic party if the district representative is Republican and the presidential vote share of the Republican party if the district representative is Democrat. Sample restrictions and political controls as in previous tables. The point estimates in this table correspond to the second stage of 2SLS regressions. 
Table A.6: Party discipline and non-discretionary spending.

\begin{tabular}{lcccccc}
\hline & $(1)$ & $(2)$ & $(3)$ & $(4)$ & $(5)$ & $(6)$ \\
\hline \multirow{3}{*}{ Unity } & \multicolumn{3}{c}{ Homogeneous effects } & \multicolumn{3}{c}{ Heterogeneous effects } \\
& 0.303 & -0.095 & -0.134 & -0.347 & -0.503 & -0.352 \\
Unity $\times$ Conflict intensity & $(0.524)$ & $(0.581)$ & $(0.586)$ & $(0.818)$ & $(0.861)$ & $(0.904)$ \\
& & & & 0.994 & 0.679 & 0.461 \\
Conflict intensity & & & & $(0.902)$ & $(0.833)$ & $(0.878)$ \\
& & & & 0.395 & 0.254 & 0.371 \\
Constant & & & & $(0.989)$ & $(0.963)$ & $(1.018)$ \\
& $(1.095)$ & $(0.955)$ & $(0.995)$ & $(1.251)$ & $(1.055)$ & $(1.106)$ \\
\hline Number of observations & 3,433 & 3,433 & 3,433 & 3,433 & 3,433 & 3,433 \\
District fixed effects & Yes & Yes & Yes & Yes & Yes & Yes \\
Year fixed effects & Yes & Yes & Yes & Yes & Yes & Yes \\
Political controls & Yes & Yes & Yes & Yes & Yes & Yes \\
Region-by-year effects & No & Yes & No & No & Yes & No \\
Division-by-year effects & No & No & Yes & No & No & Yes \\
\hline
\end{tabular}

Notes: Standard errors clustered at the district level in parentheses, ${ }^{* * *} \mathrm{p}<0.01,{ }^{*}{ }_{\mathrm{p}}<0.05,{ }^{*} \mathrm{p}<0.1$. All specifications include year and district-by-census fixed effects. The dependent variable is the log of LowVariance spending per capita. Party unity and Conflict intensity are standardized variables. Conflict intensity is the presidential vote share of the Democratic party if the district representative is Republican and the presidential vote share of the Republican party if the district representative is Democrat. Sample restrictions and political controls as in previous tables. The point estimates in this table correspond to the second stage of 2SLS regressions. 
Table A.7: Heterogeneous effects of party discipline: alternative measure of conflict.

\begin{tabular}{lcccc}
\hline & $(1)$ & $(2)$ & $(3)$ & $(4)$ \\
\hline Unity & $0.099^{* *}$ & $0.140^{* *}$ & $0.159^{* * *}$ & $0.169^{* * *}$ \\
& $(0.047)$ & $(0.058)$ & $(0.059)$ & $(0.062)$ \\
Unity $\times$ Conflict dummy & $0.090^{* *}$ & $0.091^{* *}$ & 0.064 & 0.056 \\
& $(0.045)$ & $(0.046)$ & $(0.045)$ & $(0.047)$ \\
Conflict dummy & 0.074 & 0.069 & 0.061 & 0.052 \\
& $(0.045)$ & $(0.050)$ & $(0.051)$ & $(0.051)$ \\
Constant & $4.570^{* * *}$ & $4.715^{* * *}$ & $4.702^{* * *}$ & $4.766^{* * *}$ \\
& $(0.017)$ & $(0.065)$ & $(0.064)$ & $(0.065)$ \\
\hline Number of observations & 3,433 & 3,433 & 3,433 & 3,433 \\
District fixed effects & Yes & Yes & Yes & Yes \\
Year fixed effects & Yes & Yes & Yes & Yes \\
Political controls & No & Yes & Yes & Yes \\
Region-by-year effects & No & No & Yes & No \\
Division-by-year effects & No & No & No & Yes \\
\hline
\end{tabular}

Notes: Standard errors clustered at the district level in parentheses, ${ }^{* * *} \mathrm{p}<0.01$, $* * \mathrm{p}<0.05,{ }^{*} \mathrm{p}<0.1$. All specifications include year and district-by-census fixed effects. The dependent variable is the log of High-Variance (i.e., discretionary) spending per capita. Unity is standardized. Conflict dummy $=1$ for Republican legislators who represent liberal-leaning districts or Democrat legislators who represent conservative-leaning districts. Sample restrictions and political controls as in previous tables. The point estimates in this table correspond to the second stage of 2SLS regressions. 


\section{B Politician's Maximization Problem and Proof of Lemma 3.1}

Given that $F^{\prime}(\cdot)>0$, the politician chooses policy $x \in[0, l]$ to maximize

$$
v(x)+\max [v(l-x)+\alpha, 0]= \begin{cases}v(x)+v(l-x)+\alpha & \text { if } x \geq l-v^{-1}(-\alpha), \\ v(x) & \text { if } x<l-v^{-1}(-\alpha) .\end{cases}
$$

It is decreasing in $x$ if $\frac{l}{2} \leq l-v^{-1}(-\alpha)$ (which amounts to $\alpha \leq-v\left(\frac{l}{2}\right)$ ). It follows that $x(\alpha)=0$ for $\alpha \leq-v\left(\frac{l}{2}\right)$. However, if $\frac{l}{2}>l-v^{-1}(-\alpha)$ (which amounts to $\alpha>-v\left(\frac{l}{2}\right)$ ) the politician's objective function (7) is non-monotone. In this case, there are two candidates for maximum, namely, $\arg \max _{x \in[0, l]}[v(x)+v(l-x)+\alpha]=\frac{l}{2}$ and $\arg \max _{x \in[0, l]} v(x)=0$. Evaluating (7) in $x=\frac{l}{2}$ and $x=0$ yields $2 v\left(\frac{l}{2}\right)+\alpha$ and $v(0)$, respectively. It follows that the politician chooses $x(\alpha)=\frac{l}{2}$ when $2 v\left(\frac{l}{2}\right)+\alpha \geq v(0)$ (which amounts to $\alpha \geq v(0)-2 v\left(\frac{l}{2}\right)$ ), and $x(\alpha)=0$ when $2 v\left(\frac{l}{2}\right)+\alpha<v(0)$ (which amounts to $-v\left(\frac{l}{2}\right)<\alpha<v(0)-2 v\left(\frac{l}{2}\right)$ ). To sum up, the politician picks the following policy:

$$
x(\alpha)= \begin{cases}\frac{l}{2} \quad \text { if } \quad \alpha \geq v(0)-2 v\left(\frac{l}{2}\right) \\ 0 \quad \text { if } \quad \alpha<v(0)-2 v\left(\frac{l}{2}\right) .\end{cases}
$$

Her reelection probability is equal to

$$
\operatorname{Pr}(\alpha)= \begin{cases}F\left(2 v\left(\frac{l}{2}\right)+\alpha\right) & \text { if } \quad \alpha \geq v(0)-2 v\left(\frac{l}{2}\right) \\ F(v(0)) & \text { if } \quad \alpha<v(0)-2 v\left(\frac{l}{2}\right) .\end{cases}
$$

\section{Policy- and Office-Motivated Party Leader}

Consider the model's setting with the following change. Suppose that the party leader cares not only about the policy outcome but also about the politician's reelection chances. His utility is given by

$$
u_{L}(x, s)=v(l-x)+F(v(x)+s)-s .
$$

As in the benchmark case, the leader wants the politician to internalize his losses $v(l-x)$ from the implemented policy $x$ and so will condition discretionary spending $s$ on these losses:

$$
s(x)=\max [v(l-x)+\alpha, 0] .
$$

The politician's problem is the same as in the benchmark case. We turn next to the leader's choice of $\alpha$. The party leader realizes that the politician will accept his offer and will imple- 
ment policy $x(\alpha)$ given by $(2)$. The party leader's utility $u_{L}(\cdot)$ is then equal to

$$
\begin{aligned}
u_{L}(\alpha)=v(l-x(\alpha))+F(v(x(\alpha))+ & s(x(\alpha)))-s(x(\alpha))= \\
& \begin{cases}-\alpha+F\left(2 v\left(\frac{l}{2}\right)+\alpha\right) & \text { if } \alpha \geq v(0)-2 v\left(\frac{l}{2}\right), \\
v(l)+F(v(0)) & \text { if } \quad \alpha<v(0)-2 v\left(\frac{l}{2}\right) .\end{cases}
\end{aligned}
$$

The party leader chooses $\alpha$ to maximize $u_{L}(\alpha)$, which is constant at $v(l)+F(v(0))$ for $\alpha<v(0)-2 v\left(\frac{l}{2}\right)$, discontinuously jumps to $2 v\left(\frac{l}{2}\right)-v(0)+F(v(0))$ at $\alpha=v(0)-2 v\left(\frac{l}{2}\right)$, and is a concave function for $\alpha \geq v(0)-2 v\left(\frac{l}{2}\right)$. Notice that $\arg \max _{\alpha \in \mathbb{R}}\left[-\alpha+F\left(2 v\left(\frac{l}{2}\right)+\alpha\right)\right]=$ $\left|f^{-1}(1)\right|-2 v\left(\frac{l}{2}\right)$. Therefore, the leader picks

$$
\alpha^{*}=\max \left[v(0)-2 v\left(\frac{l}{2}\right),\left|f^{-1}(1)\right|-2 v\left(\frac{l}{2}\right)\right],
$$

and offers the following spending contract to the politician

$$
s(x)=\max \left[v(l-x)+\max \left[v(0)-2 v\left(\frac{l}{2}\right),\left|f^{-1}(1)\right|-2 v\left(\frac{l}{2}\right)\right], 0\right] .
$$

Notice furthermore, that $\frac{\partial s}{\partial x} \geq 0$ and $\frac{\partial^{2} s}{\partial x \partial l} \geq 0$, as in the benchmark case. Therefore, the model predictions are robust to considering the policy- and office-motivated party leader. 